\title{
A value mapping tool for sustainable business modelling
}

\author{
Corporate Governance, Vol. 13 Iss: 5, pp.482 - 497
}

DOI: http://dx.doi.org/10.1108/CG-06-2013-0078

Bocken, N.M.P ${ }^{\dagger 1}$ Short, S. ${ }^{1}$, Rana, P. ${ }^{1}$, Evans, S. ${ }^{1}$

${ }^{1}$ University of Cambridge, Department of Engineering, Institute for Manufacturing, 17 Charles Babbage Road, Cambridge CB3 OFS, United Kingdom.

† Email: $\underline{\text { nmpb2@cam.ac.uk }}$

\begin{abstract}
Purpose - Although business models that deliver sustainability are increasingly popular in the literature, few tools that assist in sustainable business modelling have been identified. This paper investigates how businesses might create balanced social, environmental and economic value through integrating sustainability more fully into the core of their business. A value mapping tool is developed to help firms create value propositions better suited for sustainability.

Design/methodology/approach - In addition to a literature review, six sustainable companies were interviewed to understand their approaches to business modelling, using a case study approach. Building on the literature and practice, a tool was developed which was pilot tested through use in a workshop. The resulting improved tool and process was subsequently refined through use in 13 workshops.
\end{abstract}

Findings - A novel value mapping tool was developed to support sustainable business modelling, which introduces three forms of value (value captured, missed/destroyed or wasted, and opportunity) and four major stakeholder groups (environment, society, customer, and network actors).

Practical implications - This tool intends to support business modelling for sustainability by assisting firms in better understanding their overall value proposition, both positive and negative, for all relevant stakeholders in the value network.

Originality/value - The tool adopts a multiple stakeholder view of value, a network rather than firm centric perspective, and introduces a novel way of conceptualising value that specifically introduces value destroyed or wasted/ missed, in addition to the current value proposition and new opportunities for value creation.

Keywords: Business model, Business model innovation, Sustainability, Sustainable business model, Sustainable value, Value creation 


\section{Introduction}

Sustainable development is "development that meets the needs of the present without compromising the ability of the future generations to meet their own needs" (Brundtland, 1987). This implies a need for economic, social and environmental sustainability. A growing global population, coupled with changing consumption patterns creates significant challenges to health, wellbeing and the natural environment - it presents challenges of eradicating poverty, while moderating overconsumption of emerging and developed countries, which will require new socioeconomic systems that take into account the inter-linkages between population, consumption and the environment (The Royal Society, 2012).

The global challenges are significant: by 2050 the global industrial system is targeted by governments to double its output while using $50 \%$ of current resources and generating $20 \%$ of current $\mathrm{CO}_{2}$, which requires radically new approaches that may be termed "industrial sustainability" (EPSRC Centre for Industrial Sustainability, 2013). Evans et al. (2009) summarise some of the main approaches to achieve industrial sustainability: The Industrial Ecology model (Graedel, 1996); Cradle-to-Cradle, a form of industrial ecology formulated by McDonough and Braungart (2002); The Natural Step by Robèrt (2002); Sustainability by Design (Ehrenfeld, 2008), and the natural capitalism model by Lovins et al. (1999). Other industrial sustainability concepts include: cleaner production (minimising manufacturing emissions, waste, water, and energy use; Yacooub and Fresner, 2006); eco-innovation (creating competitive goods, services and processes which minimise life cycle use of resources and toxics; Reid and Miedzinski, 2008) and Corporate Social Responsibility (CSR) (businesses committing to behave ethically and contribute positively to economic development and society; Holme and Watts, 2000).

Industrial sustainability efforts to date assist industry to move in the right direction, but broadly assume that business can continue largely as usual under current assumptions of growth and incremental improvement. While they may reduce unsustainability (Ehrenfeld, 2009), the rate of change such initiatives offer appears inadequate to address growing global challenges. A fundamental paradigm shift seems necessary, in which business activities and consumption patterns are far better aligned with environmental and societal needs.

Business model redesign may be a key to radically improve sustainable performance to create greater environmental and social value while delivering economic sustainability, as suggested by Stubbs and Cocklin (2008), Porter and Kramer (2011), Yunus et al. (2010), and FORA (2010). Existing approaches to sustainability may be good for specific aspects of design and delivery, but business model innovation offers a more holistic perspective that incorporates all three dimensions of sustainability (social, environmental and economic) within business planning.

This paper investigates how companies might rethink and develop their business models to achieve enhanced industrial sustainability, and specifically investigates: What new tools could be developed to assist companies to embed sustainability into business modelling? 
To address this question, a tool and process are developed to assist in sustainable business modelling. The literature on sustainable business models, tools and value creation is reviewed in section 2 to explore the limitations of existing approaches. The methodology to develop a tool is introduced in Section 3. Section 4 discusses the development of and rationale behind a proposed value mapping tool. Refinement of the final tool and workshop process to assist in sustainable business modelling are described in Section 5. Section 6 discusses potential uses of the tool in practice, followed by concluding comments in Section 7.

\section{Literature background}

This section discusses the existing discourse on business models and emerging literature on sustainable business models and value innovation. Although the literature is evolving, few tools and processes appear to support business model innovation for sustainability.

\subsection{Business Models}

Key authors such as Chesbrough and Rosenbloom (2002), Richardson (2008), Zott and Amit (2010), Teece (2010) and Osterwalder and Pigneur (2010), have contributed to the literature on business model innovation and more particularly, business modelling processes. There appears to be reasonably good conceptual understanding of business models, albeit, with several differing perspectives (Teece, 2010; Zott et al., 2011). Teece (2010) describes that the essence of a business model is in defining the manner by which the enterprise delivers value to customers and entices customers to pay for value and converts this into profit. Osterwalder and Pigneur (2010) describe the following elements of a business model: customer segments and value proposition (value proposition), channels, customer relations; key resources, activities and partnerships (how to create value); and revenues streams and cost structure (how to capture value). Zott and Amit (2010) present the business model from an activity system perspective, viewing the business model as a network. This exemplifies an emerging view that business models need to be developed with a network-centric rather than a single firm-centric perspective.

\subsection{Sustainable Business Models}

Sustainable business models seek to go beyond delivering economic value and include a consideration of other forms of value for a broader range of stakeholders. They have been defined as business models that create competitive advantage through superior customer value while contributing to sustainable development of the company and society (Lüdeke-Freund, 2010). Stubbs and Cocklin (2008) assert that sustainable business models use both a systems and firm-level perspective, build on the triple bottom line approach to define the firm's purpose and measure performance, and include a wide range of stakeholders - in particular environment and society.

An example of a type of sustainable business model is a Product Service System (PSS) which shifts the business focus from designing, producing and selling physical products, to selling a system of products and services, to fulfil specific client demands (Manzini and Vezzoli, 2002). PSS has the potential to generate environmental benefits (Goedkoop et al., 1999) by internalising within the firm the negative 
environmental and social externalities associated with the product provision (Tukker and Tischner, 2006). This is reflected by Den Ouden (2012), who argues that by choosing the boundaries of considered ecosystems, 'externalities' can become part of the firm's decision-making.

Sustainable business models as a prerequisite must be economically sustainable. According to Schaltegger et al. (2011) the objective in sustainable business modelling is therefore to identify solutions that allow firms to capture economic value, whilst generating environmental and social value, thereby establishing the business case for sustainability.

\subsection{Value Innovation and Stakeholders}

At the core of business model innovation is re-thinking the value proposition, that is, the product /service the firm offers to its stakeholders. Conventionally, business model innovation has been about creating new forms of customer value, focusing on use value (customer benefits such as functionality, convenience, and well-being, which are often intangible); and how the firm captures value through transaction value (economic or exchange value, paid by the buyer to the producer; generally defined financially, although it may also include intangible benefits such as market access) (Bowman and Ambrosini, 2000; Allee, 2011).

To create a sustainable business, a holistic view of the value proposition is required that includes benefits and costs to other stakeholders (besides customers and the firm) and specifically to society and the environment. Building on Donaldson and Preston (1995), six stakeholder types can be observed for sustainable business models and modelling: customers, investors and shareholders, employees, suppliers and partners, the environment, and society. As Allee (2011) suggests, the consideration of value for these stakeholder groups needs to be extended explicitly. This involves understanding tangible and intangible value flows between stakeholders towards identifying relationships, exchanges and interactions, and opportunities for greater collaborative mutually beneficial value creation. Porter and Kramer (2011) define this enhanced approach as 'shared-value creation'.

\subsection{Research gap: Tools for Business Model Innovation for Sustainability}

Business model innovation for sustainability seeks to extend the delivery of positive value to all stakeholders. Many tools have been developed to assist in eco-design of products, and more generic business modelling tools have been identified. However, few tools if any have been shown to assist firms in the practical design of value propositions for business models for sustainability.

In the area of eco-design, a wide range of guideline, evaluative, comparative and trade-off tools have been developed (see Baumann et al., 2002; Byggeth and Hochschorner, 2006; Bocken et al., 2011 for some reviews). The tools may assist in evaluating the environmental aspects (e.g. durability, reusability) of products to improve design, although few tools focus on idea generation (with some exceptions, e.g. Bocken et al., 2011). 
The 'business model canvas' (Osterwalder and Pigneur, 2010) is a popular framework to support the generic business modelling process. While being well-conceived and academically grounded, it has a narrow view of the value proposition focusing only on the customer. As such, it seems poorly suited for assisting a firm in generating wider sustainability across the full stakeholder network - including suppliers, local communities, and the wider society and the environment (which may be represented by NGOs or the government). Expert facilitation would be required to adapt the tool to different (i.e. sustainability) contexts. Similar limitations can be observed of other popular tools for value proposition innovation, such as blue ocean strategy (Kim and Mauborgne, 2005).

Network-centric tools for business model innovation (which go beyond considering customer value) are less developed, and are generally conceptual to date. Tools such as Allee's (2011) Value Network Analysis (VNA) offer an approach to value transformation and understanding value creation, which might assist in business modelling. However, VNA maps are complicated and time-consuming to develop, and not specifically intended for business modelling. Den Ouden's value framework (Den Ouden, 2012) offers an approach for developing a value proposition that benefits a network of stakeholders for 'meaningful innovations' using perspectives on value from economics, psychology, sociology and ecology. Den Ouden's framework explores value across user, organisation, business ecosystem, and society for business innovations. However, the concepts and terminology may be too complex to engage workshop participants in a business environment.

To summarise, existing tools generally tend to focus on just one dimension of sustainability (e.g. environment, economic value), and fail to engender a holistic perspective that incorporates all three dimensions of sustainability within the business planning process. Moreover, current tools and methods are either conceptual or have not been used widely in industry, and generally rely on a well-trained (external) facilitator.

This paper identifies a need for a tool to assist firms in better understanding sustainable value creation within their business activities, and assist them in developing new business models with sustainability at their core. Such business model development should seek to better balance value creation for all stakeholders to eliminate conflicting demands and negative outcomes for any of the stakeholders. This paper introduces a tool and process to systematically rethink the positive and negative value created for all stakeholders through the business model.

\section{Research method}

Despite the shortfalls in tools and methods in the literature, there are an increasing number of practical examples of firms successfully exploring and innovating for sustainability. Case studies followed by a testing phase through the use of workshops were conducted to develop, test and improve a proposed tool. 


\subsection{Case study analysis}

Case studies were conducted by interviewing six firms perceived to be actively engaging in business model innovation for sustainability, and collecting company documentation and articles from the popular press discussing their activities.

The selected firms were spread across a range of industry sectors, and include startups, small and medium size enterprises (SMEs) and multinational companies (MNCs). Recommendations from sustainability experts in academia and practice including rankings, indices and sustainability awards and media coverage on sustainability leaders were used to identify companies at various stages of transformation towards sustainability (from best in class to aspiring). The criteria for the selection of the firms were as follows:

- Recognition by industry peers as providing leadership in sustainability (at minimum)

- Actively engaging in business model innovation for sustainability

The above criteria assisted in establishing the suitability of the six firms (Table 1). Founders and senior staff of the firms were interviewed using a semi-structured interview technique. Interviews typically lasted 2-3 hours, and the following themes were explored:

- The role of sustainability in the company, sustainability governance and how sustainability has evolved in the business

- The drivers for sustainability and why the company has gone further than most

- Sustainability within the business modelling process (if there is such a process)

- How their sustainability innovations were conceived and developed

\begin{tabular}{|l|l|l|l|}
\hline $\begin{array}{l}\text { Manufacturing } \\
\text { sector }\end{array}$ & $\begin{array}{l}\text { Evidence of sustainability in } \\
\text { business operations }\end{array}$ & $\begin{array}{l}\text { Organisation } \\
\text { type, location }\end{array}$ & Interviewees \\
\hline 1 Automotive & $\begin{array}{l}\text { PSS and novel governance } \\
\text { system }\end{array}$ & Start-up, UK & $\begin{array}{l}\text { Joint interview with the } \\
\text { founder and engineer }\end{array}$ \\
\hline 2 Cleaning & $\begin{array}{l}\text { Breakthrough cleaning } \\
\text { mechanisms with significantly } \\
\text { reduced water and energy use }\end{array}$ & Start-up, UK & Technical director \\
\hline 3 Furniture & $\begin{array}{l}\text { A business philosophy against } \\
\text { consumerism, promoting social } \\
\text { and environmental awareness }\end{array}$ & SME, UK & Managing director \\
\hline Agriculture & On a journey to a PSS & $\begin{array}{l}\text { Multinational, } \\
\text { Germany }\end{array}$ & $\begin{array}{l}\text { Joint interview with } \\
\text { service engineer and } \\
\text { product manager }\end{array}$ \\
\hline 6 Printing & $\begin{array}{l}\text { Industrial Symbiosis - using } \\
\text { waste as an input }\end{array}$ & $\begin{array}{l}\text { Multinational, UK } \\
\text { and reusable packaging }\end{array}$ & Sustainability director \\
\hline
\end{tabular}

Table 1. List of interviewees.

Note. Case studies took place between October 2011 - January 2012

\subsection{Workshops to further develop the tool}

Based on the literature and case study analysis, a tool was developed (Section 4) to assist in sustainable business modelling, which was tested through workshops. The tool was used with the six case study companies in Table 1 (sessions 1-6 in Table 2) and with other organisations of varied scales. It was decided to first test the tool with the six case study companies to evaluate whether it would have helped them in their 
thinking to develop their current sustainable business model and whether it could help them move to an even more sustainable business model.

The aims of all the workshops included: to test the effectiveness of the tool; to explore opportunities to refine the tool; and explore facilitation methods to best use the tool. At the end of the workshops, structured feedback was gathered from participants by using a workshop evaluation schedule to evaluate perceived usefulness and help refine the tool and the facilitation process for using the tool.

\begin{tabular}{|c|c|c|c|c|}
\hline $\begin{array}{l}\text { Session number } \\
\text { and Sector } \\
\text { investigated }\end{array}$ & $\begin{array}{l}\text { Organisation } \\
\text { type, location }\end{array}$ & $\begin{array}{l}\text { Type of } \\
\text { participants }\end{array}$ & $\begin{array}{l}\text { Number of workshop } \\
\text { participants (not } \\
\text { authors) }\end{array}$ & $\begin{array}{l}\text { Additional tool or } \\
\text { process elements } \\
\text { tested }\end{array}$ \\
\hline 1 Food & Multinational, UK & Industry & 1 & \\
\hline 2 Automotive & Start-up, UK & Industry & 2 & $\begin{array}{l}\text { Use of expanded } \\
\text { introduction to tool }\end{array}$ \\
\hline 3 Cleaning & Start-up, UK & Industry & 1 & $\begin{array}{l}\text { Use of blank } \\
\text { stakeholder segments }\end{array}$ \\
\hline 4 Agriculture & $\begin{array}{l}\text { Multinational, } \\
\text { Germany }\end{array}$ & Industry & 3 & \\
\hline 5 Furniture & SME, UK & Industry & 1 & \\
\hline 6 Printing & Multinational, UK & Industry & 1 & $\begin{array}{l}\text { Alternative processes } \\
\text { of facilitation }\end{array}$ \\
\hline 7 Retail & International, UK & Industry & 2 & $\begin{array}{l}\text { Alternative processes } \\
\text { of facilitation }\end{array}$ \\
\hline 8 Clothing & $\begin{array}{l}\text { International, } \\
\text { Netherlands }\end{array}$ & $\begin{array}{l}\text { Mix of non-profit, } \\
\text { business and } \\
\text { academics, } \\
\text { Netherlands, }\end{array}$ & $\begin{array}{l}10 \text { (1 large group, } 1 \\
\text { topic) }\end{array}$ & $\begin{array}{l}\text { Examples to prompt } \\
\text { discussion. Multiple } \\
\text { stakeholders as } \\
\text { participants }\end{array}$ \\
\hline 9 Footwear & $\begin{array}{l}\text { International, } \\
\text { Netherlands }\end{array}$ & $\begin{array}{l}\text { Mix of non-profit, } \\
\text { business and } \\
\text { academics, } \\
\text { Netherlands, }\end{array}$ & $\begin{array}{l}15 \text { (1 large group, } 1 \\
\text { topic) }\end{array}$ & $\begin{array}{l}\text { Examples to prompt } \\
\text { discussion. Multiple } \\
\text { stakeholders as } \\
\text { participants }\end{array}$ \\
\hline $\begin{array}{l}10 \text { Automotive } \\
\text { and Steel } \\
\text { producers }\end{array}$ & $\begin{array}{l}\text { Multinationals, } \\
\text { Italy }\end{array}$ & $\begin{array}{l}\text { University, Italy, } \\
\text { Engineering } \\
\text { graduates }\end{array}$ & $\begin{array}{l}10 \text { ( } 2 \text { groups of } 5 \\
\text { students to explore two } \\
\text { separate company cases) }\end{array}$ & $\begin{array}{l}\text { Simplifying the tool } \\
\text { and process }\end{array}$ \\
\hline $\begin{array}{l}11 \text { Consumer } \\
\text { products }\end{array}$ & $\begin{array}{l}\text { Various, SME to } \\
\text { Multinational, UK }\end{array}$ & $\begin{array}{l}\text { University, UK, } \\
\text { Engineering and } \\
\text { Management } \\
\text { undergraduates }\end{array}$ & $\begin{array}{l}30 \text { (6 groups of } 5 \\
\text { students, each with own } \\
\text { case) }\end{array}$ & $\begin{array}{l}\text { Simplified tool and } \\
\text { process, using } \\
\text { examples }\end{array}$ \\
\hline $\begin{array}{l}12 \text { Consumer } \\
\text { products }\end{array}$ & $\begin{array}{l}\text { Various, SME to } \\
\text { Multinational, UK }\end{array}$ & $\begin{array}{l}\text { University, UK, } \\
\text { Engineering and } \\
\text { Management } \\
\text { graduates }\end{array}$ & $\begin{array}{l}40 \text { ( } 8 \text { groups of } 5 \\
\text { students, each group } \\
\text { with own case) }\end{array}$ & $\begin{array}{l}\text { Simplified tool, } \\
\text { using examples }\end{array}$ \\
\hline $\begin{array}{l}13 \text { Automotive, } \\
\text { agriculture, IT }\end{array}$ & $\begin{array}{l}\text { Various: start-up, } \\
\text { SME, } \\
\text { Multinational, UK }\end{array}$ & Industry & 15 (3 groups of 5 ) & $\begin{array}{l}\text { Using predefined } \\
\text { prompt questions }\end{array}$ \\
\hline
\end{tabular}

Table 2. List of workshop participants.

Note: Workshops took place between June-November 2012 and are listed in chronological order 


\section{Development of a value mapping tool}

This section presents the findings from the case studies and explains the rationale and development of a value mapping tool.

\subsection{Findings from the case studies}

Several common themes emerged from the case studies, which further confirmed the need to develop a tool for mapping value.

First, there is a common recognition by the interviewees (Table 1) for the need for innovation to embed sustainability in the business by considering environmental and social value, which is not typically done because of an economic/ customer focus in conventional businesses. Second, there are limited tools that can be used by companies to develop novel business models and forms of value across the stakeholder network. Innovation has been approached generally in an ad-hoc, experimental manner, rather than using specific tools or a prescriptive process. Third, innovations often target negative impacts of business, and seek to reduce waste. This appears distinct from seeking new opportunities for customer-orientated value creation. Interviewees were not aware of tools that might enable users to explore both simulatenously to improve the business model. Finally, innovations often involve development of new collaborations extending beyond the traditional company network, not uncommonly involving new actors from industry sectors not traditionally linked to the firm (e.g. partnerships with NGOs).

The literature review and case study research identified the need to distinguish different forms of value. Figure 1 shows a conceptual portfolio for value innovation opportunities for a firm and its stakeholders developed in this research.

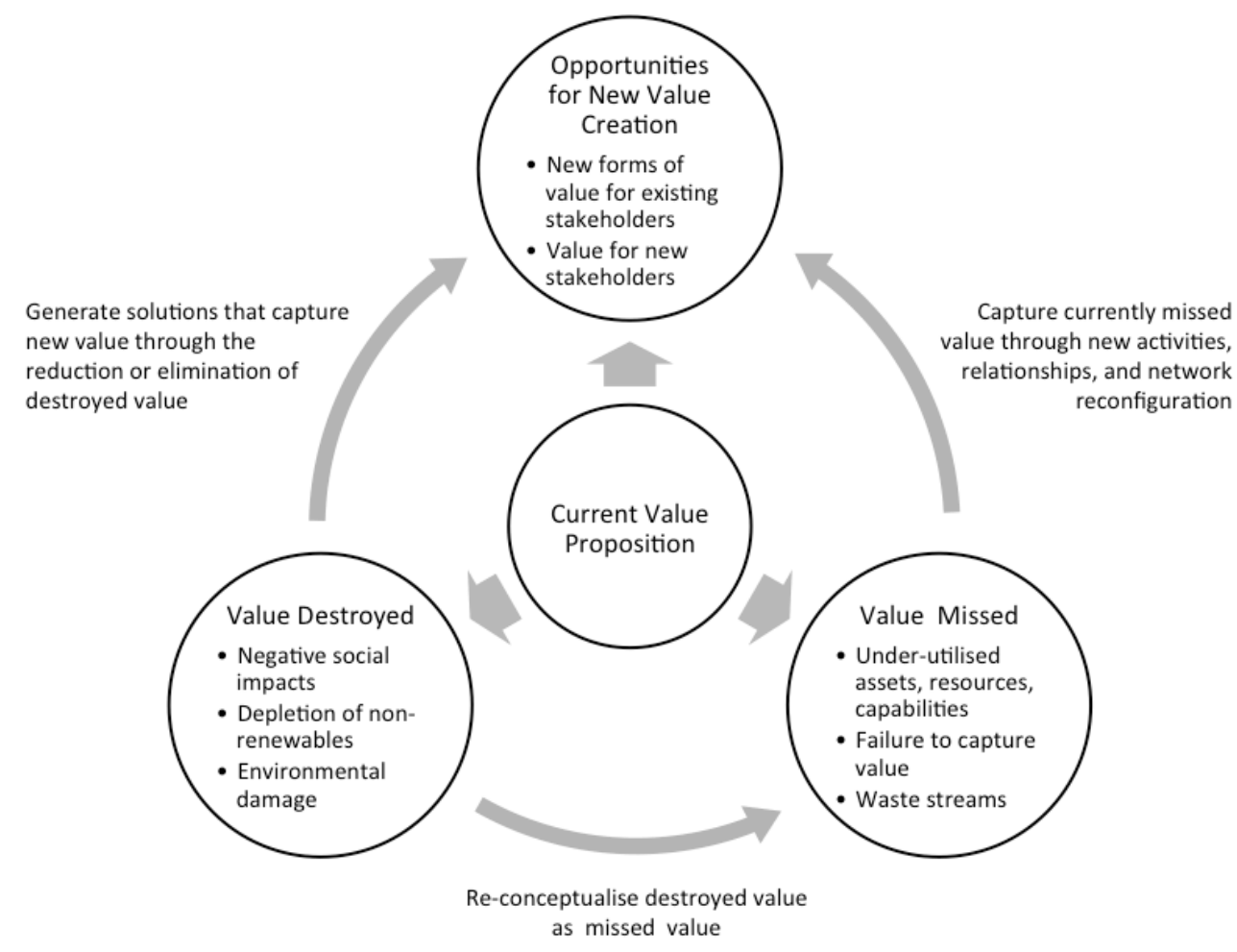

Figure 1. Opportunities for value innovation 
At the core of this portfolio is the value proposition of the network, which represents the benefits delivered to stakeholders for which payment or another value exchange takes place. In delivering the value proposition, individual stakeholders and networks collectively may destroy value. Value destroyed can take various forms, but in the sustainability context is mostly concerning damaging environmental and social impacts of business activities (e.g. pollution). These are often referred to as 'negative externalities' in literature, but it is felt that this terminology could artificially distance these impacts from the firm. Missed value opportunities represent situations where individual stakeholders squander or fail to capitalise on existing assets, resources and capabilities, are operating below industry best practice, or fail to receive the benefits they seek from the network. This might be due to poorly designed value creation or capture systems, failure to acknowledge value, or inability to persuade others to pay for the benefit. New value opportunities help expand the business into new markets and introduce new products and services that offer enhanced benefits to stakeholders. Beyond customers, this might involve seeking to enhance employee wellbeing or making positive contributions to the environment.

\subsection{The Value Mapping Tool}

A "value mapping tool" is conceived to help companies create value propositions to support sustainable business modelling. The tool adopts a qualitative approach to value analysis. Although quantitative analytical tools are useful supportive tools, often used in the area of sustainability (e.g. Life Cycle Assessment and scenario analysis; see Allwood et al., 2008) the proposed use of the value mapping tool at the business modelling level does not necessitate such quantitative detail, because its primary aim is to stimulate idea generation and discussion.

The tool has the following specific aims:

- Understand the positive and negative aspects of the value proposition of the value network (i.e. the network of stakeholders involved in creation, delivery and receipt of value associated with provision of a product/service);

- Identify conflicting values (i.e. where one stakeholder benefit creates a negative for another stakeholder), so that action can be taken to tackle these;

- Identify opportunities for business model redesign and realignment of interests to reduce negative outcomes and improve the overall outcome for the stakeholders in the value network - especially for society and the environment

Ease of use and the limited need for expert facilitation was considered in the development of the tool. Based on the insights on value innovation, a value mapping tool was developed as shown in Figure 2. 


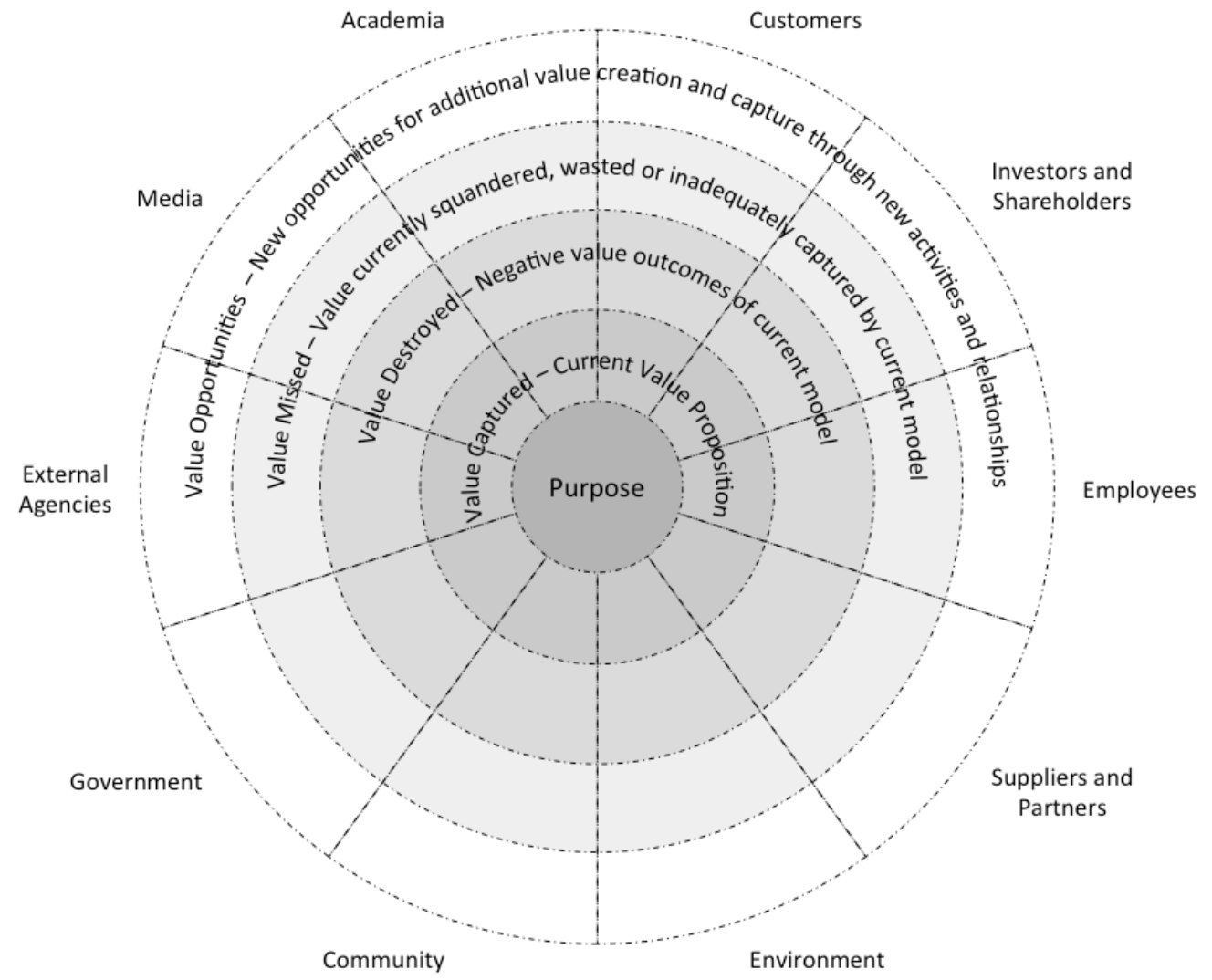

Figure 2. Value Mapping Tool

The circular form of the tool was developed over a series of discussions and a pilot study, to facilitate a system-perspective of value, encourage equal consideration of all stakeholder interests, and explore the inter-relatedness between different stakeholders. Alternative formats such as tabular format were tested during the pilot study, but the circular tool was considered most effective to engage the participants and better stimulate creative lateral thinking.

The novel design aspects of the tool include:

- Four representations of value to facilitate a systematic value assessment, representing the forms of value in Figure 1. Identifying them separately encourages a more thorough exploration of the current business model, and assists in identifying areas requiring change or improvement.

- Stakeholder segments to facilitate a multiple stakeholder view of value. Current business modelling processes and tools focus on the customer value proposition. The proposed tool seeks to expand the range of stakeholders or recipients of value, including the environment and society. Each segment represents a stakeholder group.

- A network centric rather than firm centric perspective to encourage the optimisation of value in a network (i.e. considering all actors involved in the 
design, production and distribution of a product or service). The firm is represented as "employees and shareholders" to facilitate a network perspective.

Organisations while brainstorming may want to consider competitors and competing value propositions while using the tool. However, the tool is intended to map out and transform the business model of a firm to deliver sustainability, rather than serving the purpose of competitor analysis. Hence, competitors are not explicitly included.

\section{Results from workshop evaluation trials}

As discussed in Section 3.2, a series of 13 workshops were conducted to test the tool shown in Figure 2. The objectives of the workshops included: investigation of the effectiveness of the tool for exploring positive and negative value outcomes of the existing busines model and suitability of the tool for providing a structure for systematically considering how to modify the business model to tackle negatives and identify new opportunities. Additionally, techniques to facilitate the workshop and stimulate brainstorming and supporting tools were investigated.

\subsection{Simplified Version of the Value Mapping Tool}

Overall, the tool and its design and use were understood and well received. It was considered helpful in focusing on destroyed and missed value, understanding exchange of value across the network, and for capturing sustainability and business model innovation opportunities. Particularly, the tool was thought to be good in engaging participants of each firm to generate ideas and priority areas for sustainability. However, upon reflection of the main results, it was found that a simplified version of the tool could be developed - including fewer stakeholder segments by grouping some stakeholder types together, and merging the value destroyed and missed rings.

The number of stakeholders were reduced to four (environmental, social, customers, and network actors) to reduce the time required for the workshop. It was observed that several stakeholder segments led to similar discussions and value maps. For example, environmental NGOs and environment can be merged without significant loss of detail and government, community, and employees can be grouped under 'society' to explore societal values. Building on definitions of value in Section 2, a distinction is made between those stakeholders that are part of the value-creating network refered to as 'network actors' (the focal firm, investors, suppliers, partners, distribution channels, and in some cases also media, academia and other specific participants) and those that receive the direct benefits or impacts of the product or service (customers, environment, society). Customers are distinct from society as they receive specific benefits which may not be societal (e.g. owning a sportscar may bring considerable personal benefits to the user, but these are not societal benefits). However, some customer benefits (e.g. communal green spaces in cities) have a wider positive societal impact (e.g. creating the sense of community). Recognising these potentially conflicting and reconciling ideas of value is an essential part in redesigning the business model.

During some of the workshops, the brainstorming on 'value missed' and 'value destroyed' led to similar ideas being generated, creating significant, and sometimes unbeneficial debate over exactly which ring they best fitted. Upon further 
consideration, the two rings were merged into one to reduce this debate. Some detail and opportunity for discussion is lost in making this simplification, but if time is limited for the workshop this seems a reasonable compromise. Hence, depending on time availability Figure 2 might be used for deeper thinking on various forms of value (distinguishing value missed and destroyed) while Figure 3 might be used for a quicker, higher level assessment.

Figure 3 shows the simplified tool (Appendix A shows a populated example). This simplified tool was used during workshop sessions 11 and 12 in Table 2.

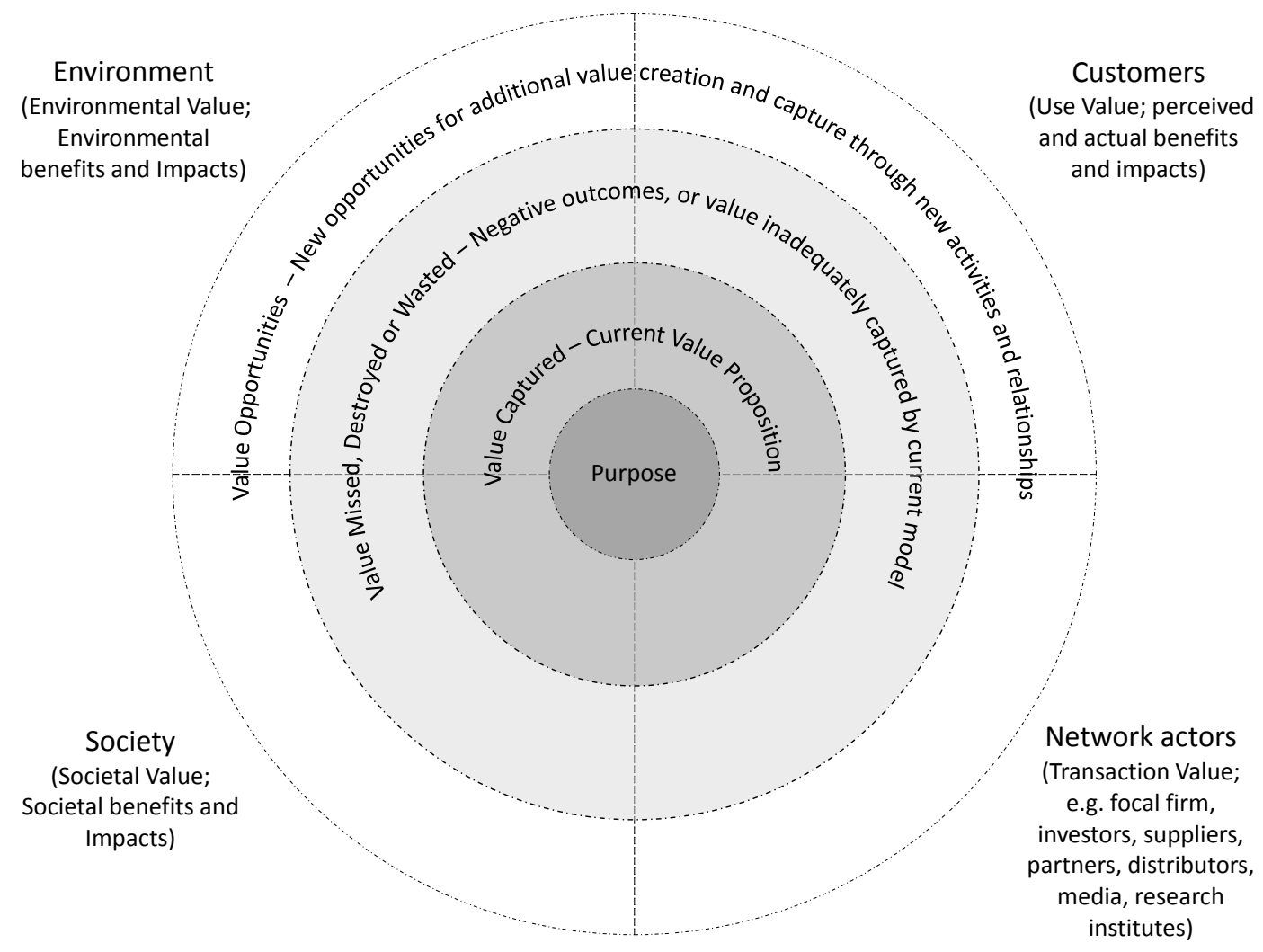

Figure 3. Simplified value mapping tool

\subsection{The Value Mapping Process - Using the Tool}

This section discusses how the value mapping tool might be used in practice. Either of the two forms of the tool presented here may be used. The simplified tool is appropriate for a shorter workshop, but may not provide quite as much depth and discussion as the original tool. The choice of tool is dependent on the time available and level of analysis desired. Based on the workshop experiences, a value mapping process is proposed, applicable to either of the two tools in Figures 2 and 3.

\section{Pre-workshop preparation:}

- Invite appropriate participants to represent each of the main stakeholders or stakeholder groupings considered relevant to the business. Ideally these would be representatives of each group, but this may not always be possible due to logistics, 
confidentiality, or other considerations. At least there should be a proxy representation (e.g. procurement manager as proxy for suppliers, sustainability manager as proxy for environment, marketing manager as proxy for customers) to develop various perspectives on value.

- A discussion should take place with the workshop participants to determine the general level of awareness and understanding of key issues in sustainability.

\section{Workshop process:}

The workshop process follows several steps:

- Depending on the familiarity with sustainability a short or long introduction of the key global sustainability challenges (as highlighted in Section 1) is given.

- A short introduction is given on the tool with an example of a populated tool. Real business examples will help illustrate the terminology of value captured, missed, value, new opportunities and how value forms might be transformed.

- Subsequently, workshop participants should define the unit of analysis as the product or service, or portfolio of products and services offered by a business unit, firm, or industry. For large companies a focus on individual business units or product lines can make the process more manageable.

- Stakeholder groups are identified by the participants, and placed in each segment of the tool, and representatives of each group are nominated. For the more complex version of the tool, the starting point is generic stakeholder types, but the tool may be populated with additional specific stakeholders.

- The purpose is discussed: the top-level description of why the organisation is in operation (e.g. fairtrade intends to improve the living standards of workers and communities in global supply chains). The focus is on the offering, rather than the firm, to support a network or system perspective.

- A facilitated brainstorming is then used to populate the tool (a guide for facilitators with example questions is available upon request from the authors).

- Each stakeholder segment is populated in turn with the various forms of value generated for that stakeholder, starting at the centre of the circle and working outwards: from purpose and value proposition, to value destroyed and missed, through to exploring new opportunities for value creation.

- By following this progression each step builds upon and is informed by each preceding step facilitating ideas for transformation as illustrated in Figure 1. For instance, missed value can be explored for opportunities to create new value.

- After this core part of the process, the ideas voted to be most promising might be used for further brainstorming.

\section{Facilitation:}

- A set of pre-defined prompt questions (available upon request) helps to reduce dependency on the external facilitator and navigate the discussion.

- Consider a methodical approach (e.g. colour-coding) to writing on post-its as illustrated in Appendix A. 
- Project the tool on a wall or screen to save paper during the group brainstorms.

- Capturing the final results with a camera ensures all details are recorded. Transcribing the final details in a tabular form containing a row/ column for each individual brainstorm (e.g. value missed, opportunity) was found to be helpful.

\section{Discussion}

The value mapping tool assists companies in embedding sustainability into the core of the business model through an improved understanding of the value proposition. It supports an iterative process for analysing sustainable value creation opportunities from a multi-stakeholder perspective.

The tool and facilitation process can be constructively used as a stand-alone tool to assist firms and their stakeholders in exploring forms of value and generating ideas on where and how to transform the value proposition, but it can also be used as part of a more comprehensive exercise of value mapping and transformation in conjunction with supplementary tools. These tools could extend the analysis of value and opportunities; assist in prioritising (e.g. Bocken et al., 2012), exploring potential transformation paths and planning the evolution of the business model (e.g. Phaal et al. 2004; Osterwalder and Pigneur; 2010). The following sections discuss potential value mapping tool applications and supporting tools.

\subsection{Applicability for the value mapping tool}

The two versions of the tool presented in this paper may suit different situations. The more comprehensive tool (Figure 2) takes longer to use, but allows for a more indepth investigation of value exchanges across a detailed list of stakeholders, including specific ones (e.g. important partners, customer segments) that may be identified by the workshop participants. The more comprehensive tool stimulates more discussion and debate. Conversely, the simplified tool (Figure 3) provides less depth but appears sufficient for a quick assessment of key issues. Overall, it was observed that both versions have an engaging, easy to use format for group discussion.

The workshops (Section 5) were conducted with a variety of organisations in different environments. The proposed value mapping tools are conceived to facilitate exploration of sustainable value within multi-stakeholder network collaborations. Dauvergne and Lister (2013) highlight an increasing number of large corporations initiating collaborative sustainability governance within networks. This involves engaging proactively with a broader range of stakeholders, often including nonindustry actors (e.g. WWF partnering with Coca-Cola) and competitors to establish industry-level sustainability consortia (e.g. The Sustainable Apparel Coalition). In such applications, the tool could be expanded to include all specific stakeholders, and as discussed by Dauvergne and Lister (2013) could be used in visioning exercises to explore stakeholders' views of value. The tool could be used to assist students in thinking about broader issues of sustainability and in exploring case studies on sustainable business models, making it suitable for educational purposes. For policy makers it could serve as a framework for macro-level analysis of industry.

The value mapping tool has been tested with non-profits and students and might be adapted to suit specific workshop objectives. Planned future testing in a range of 
sectors, companies, non-profits, social enterprise would help to understand the wider applicability and versatility of the tool and improve the process.

\subsection{Business analysis tools}

Business analysis tools might help to extend the analysis of value opportunities by considering potential changes in technology, legislation, social change, environmental pressures and competition that affect the business environment. Phaal et al. (2012) suggest a 'modular toolkit' that is used in a workshop setting to support strategic technology and innovation management. Tools such as SWOT (to assess strengths, weaknesses, opportunities and threats), PEST (to assess macro-level political, economic, social, and technical factors), competitor analysis (to assess emerging threats and opportunities) and scenario analysis might be used. These tools assist in understanding the current system and identifying requirements for the future that will affect the development and transformation towards a sustainable business model. Such analysis may be supplemented with social and environmental analysis tools such as Life Cycle Analysis to gain deeper insights in the social and environmental impacts of a product (e.g. Allwood et al., 2008). Although the value mapping has been proven to be useful on its own, these tools might give additional support in identifying forms of positive and negative value over time.

\subsection{Tools for transforming the value proposition}

During normal workshop facilitation, examples may be given to stimulate idea generation, but more structure can be given to this process. A potential practical approach to facilitate this innovation process as suggested by Short et al. (2012) uses a typology of business model archetypes to describe innovations for sustainability. This typology (Table 3) was used to prompt generation of new ideas in workshop sessions $8,9,11$ and 12. This approach assists participants in seeking ways to transform negatives into positive outcomes, to tackle conflicting stakeholder demands and seek new ways to create sustainable value. Moreover, the archetypes facilitate learning from cross-industry perspectives. 


\begin{tabular}{|l|}
\hline Sustainable Business Model Archetypes \\
\hline 1. Maximise material and energy efficiency \\
(Do more with less resources, generating less waste, emissions and pollution) \\
2. Create value from 'waste' \\
(Turn waste streams, emissions, and discarded products into feed stocks for other products and processes, and \\
make best use of under-utilised capacity) \\
3. Deliver functionality, rather than ownership \\
(Provide services that satisfy users' needs without having to own physical products) \\
4. Encourage sufficiency \\
(Solutions that actively seek to reduce consumption and production) \\
5. Adopt a stewardship role \\
(Proactively engaging with all stakeholders to ensure their long-term health and well-being) \\
6. Re-purpose the business for society/environment \\
(Focusing the business on delivering social and environmental benefits, rather than economic profit \\
maximisation) \\
7. Integrate business in the community \\
(Integrating business back into local communities through employee ownership and collaborative approaches to \\
business) \\
8. Develop scale-up solutions \\
(Delivering sustainable solutions at a large scale to maximise benefits for society and the environment) \\
9. Radical innovation \\
(Introduce system change through introduction of radical new technologies to facilitate a greener economy) \\
Table 3. Sustainable business model archetypes. Adapted from Short et al. (2012)
\end{tabular}

Table 3. Sustainable business model archetypes. Adapted from Short et al. (2012)

\subsection{Developing the plan for implementing the new value proposition}

It was observed that the transformation of a company's value proposition generally requires a sequence of continuous improvement steps to develop new capabilities and change "how the company does business" engaging the workforce and managers, suppliers, customers, and the company's broader stakeholders. The evolution of the business model may take time because of the need for reconfiguration and coordination of activities, resources, partnerships and revenue models (Osterwalder and Pigneur, 2010). Therefore, after the value mapping brainstorm, a group discussion can take place to plan future actions. An example of a strategy tool to facilitate this process and plan future actions is roadmapping. Phaal et al. (2004) view roadmaps as powerful communication tools, which allow people from various functional backgrounds to work together on a shared future vision. This may be useful to support the transition to sustainable business models.

\section{Conclusion}

Business model innovation seems a key to delivering future sustainability. The tool developed in this paper (presented in two formats) is intended as a primary step in a business modelling process for embedding sustainability into the core purpose of the firm and its network of stakeholders. The apparent simplicity of the tool is an important strength ensuring ease of understanding and use. It is effective in raising awareness of the often conflicting values and negative outcomes of business activities, to support organisations on the journey towards sustainability. However, the tool does 
require some facilitation to get the best results - in part because of the need for sustainability innovation to look outside existing business practices, where external participants and facilitators can help to bring that new perspective.

The tool is envisaged to have applicability to all organisations, from exploring opportunities for new start-ups, assisting in redesigning business models of established large corporations, to use in public sector and non-government organisations. Preliminary workshops have demonstrated the potential for conceptualising and assisting in value transformation. As the tool is just one step in a business modelling process, further work is recommended to refine and enhance a complete toolset to assist in developing complete solutions to transform the business model. More tests are planned to further understand the applicability and suitability of the tool in different contexts.

\section{References}

Allee, V. (2011), "Value Networks and the true nature of collaboration" Online Edi., ValueNet Works and Verna Allee Associates, available at:

http://www.valuenetworksandcollaboration.com/ (accessed 3 March 2013).

Allwood, J., Ellebæk Laursen, S., Russell, S., Malvido de Rodríguez, C. and Bocken, N. (2008). "An approach to scenario analysis of the sustainability of an industrial sector applied to clothing and textiles in the UK", Journal of Cleaner Production, Vol. 16 No. 12, pp. 1234-1246.

Baumann, H., Boons, F. and Bragd, A. (2002), "Mapping the green product development field: engineering, policy and business perspectives", Journal of Cleaner Production, Vol. 10, pp. 409-425.

Bocken, N., Allwood, J., Willey, A. and King, J. (2011), "Development of an ecoideation tool to identify stepwise greenhouse gas emissions reduction options for consumer goods", Journal of Cleaner Production, Vol. 19 No. 12, pp. 1279-1287.

Bocken, N., Allwood, J., Willey, A. and King, J. (2012), "Development of a tool to rapidly assess implementation difficulty and emissions reduction benefits of innovations", Technovation, Vol. 32 No. 1, pp. 19-31.

Bowman, C. and Ambrosini, V. (2000), "Value Creation versus Value Capture: Towards a Coherent Definition of Value in Strategy", British Journal of Management, Vol. 11, pp. 1-15.

Brundtland, H. (1987), Our Common Future, Oxford University Press, Oxford.

Byggeth, S. and Hochschorner, E. (2006), "Handling trade-offs in Ecodesign tools for sustainable product development and procurement", Journal of Cleaner Production, Vol.14, pp. 1420-1430.

Chesbrough, H. and Rosenbloom, R. (2002), "The role of the business model in capturing value from innovation: evidence from Xerox Corporation's technology spinoff companies", Industrial and Corporate Change, Vol. 11 No. 3, pp. 529-555. 
Dauvergne, P. and Lister, J., (2013), Eco-Business: A Big-Brand Takeover of Sustainability, 1st ed., MIT Press, Cambridge, MA.

Den Ouden, E. (2012), Innovation Design. Creating value for people, organizations and society, Springer-Verlag, London.

Donaldson, T. and Preston, L. (1995), "The Stakeholder theory of the Corporation: Concepts, Evidence, and Implications." The Academy of Management Review, Vol. 20 No. 1, pp. 65-91.

Ehrenfeld, J. (2008), Sustainability by design. A subversive strategy for transforming our consumer culture, Yale University Press, New Haven.

Ehrenfeld, J. (2009), "Understanding of Complexity Expands the Reach of Industrial Ecology”, Journal of Industrial Ecology, Vol. 13, pp. 165-167.

EPSRC Centre for Industrial Sustainability (2013). Challenge. Available at: http://www.industrialsustainability.org/about-us/challenge/ (accessed 22 April 2013).

Evans, S., Norell Bergendahl, M., Gregory, M. and Ryan, C. (2009), "Towards a sustainable industrial system: accelerating the contribution of education and research", University of Cambridge, Institute for Manufacturing and Cranfield University. Available at: http://www.ifm.eng.cam.ac.uk/research/industrialsustainability/initiatives/sustainable-industrial-systems/ (accessed 22 April 2013).

FORA (2010), "Green business models in the Nordic Region: A key to promote sustainable growth", FORA, Denmark. Available at:

http://www.danishwaterforum.dk/activities/Water_and_green_growth/greenpaper_for a_211010_green_business models.pdf (accessed on 13 May 2013).

Goedkoop, M., van Halen, J., te Riele, H. and Rommens, P. (1999), Product service systems, ecological and economic basics, Ed Vrom EZ, The Hague.

Graedel, T. (1996), "On the concept of industrial ecology", Annual Review of Energy and the Environment, Vol. 21 Issue 1, pp. 69-98.

Holme, R. and Watts, P. (2000), "Corporate Social Responsibility - making good business sense”, World Business Council for Sustainable Development, Geneva, Switzerland. Available at http://www.wbcsd.org/web/publications/csr2000.pdf (accessed on 23 April 2013).

Kim, W. and Mauborgne, R. (2005), Blue Ocean Strategy: How to Create Uncontested Market Space and Make the Competition Irrelevant, Harvard Business Review Press, Boston.

Lovins, A., Lovins, L. and Hawken, P. (1999), “A Road Map for Natural Capitalism”, Harvard Business Review, May-June, pp. 145-158. 
Lüdeke-Freund, F. (2010), "Towards a Conceptual Framework of 'Business Models for Sustainability", Wever, R., Quist, J., Tukker, A., Woudstra, J., Boons, F. and Beute, N. (Eds.), Knowledge collaboration \& learning for sustainable innovation, Delft, The Netherlands. Available at http://papers.ssrn.com/sol3/papers.cfm?abstract_id=2189922 (accessed on 13 May 2013).

Manzini, E. and Vezzoli, C. (2002), Product-Service Systems and Sustainability, UNEP, Paris.

McDonough, W. and Braungart, M. (2002), Cradle-to-Cradle: Remaking the way we make things, North Point Press, New York.

Osterwalder, A. and Pigneur, Y. (2010), Business Model Generation: A Handbook for Visionaries, Game Changers, and Challengers, John Wiley \& Sons, Hoboken, NJ.

Phaal, R., Farrukh, C. and Probert, D. (2004), "Technology roadmapping - A planning framework for evolution and revolution”, Technological Forecasting \& Social Change, Vol. 71, pp. 5-26.

Phaal, R., Kerr, C., Oughton, D. and Probert, D. (2012), "Towards a modular toolkit for strategic technology management", International Journal of Technology Intelligence and Planning, Vol. 8 No. 2, pp. 161-180.

Porter, M. and Kramer, M. (2011), "Creating Shared Value”, Harvard Business Review, January, pp. 1-17.

Richardson, J. (2008), "The business model : an integrative framework for strategy execution”, Strategic Change, Vol. 17 No. 5-6, pp.133-144.

Reid, A. and Miedzinski, M. (2008), "Eco-innovation: Final report for sectoral Innovation Watch", Technopolis group. Available at: http://www.technopolisgroup.com/resources/downloads/661_report final.pdf (accessed 14 January 2012).

Robèrt, K. (2002), The Natural Step Story: Seeding a Quiet Revolution, BC: New Society Publishers, Gabriola Island.

Schaltegger, S., Lüdeke-freund, F. and Hansen (2011), Business Cases for Sustainability and the Role of Business Model Innovation Developing a Conceptual Framework, Lueneburg: Centre for Sustainability Management (CSM), Leuphana University of Lueneburg, Lueneburg.

Short, S.W., Bocken, N.M.P., Rana, P. and Evans, S. (2012), "Business Model Innovation for Embedding Sustainability: A Practice-Based Approach Introducing Business Model Archetypes", in proceedings of the 10th Global Conference on Sustainable Manufacturing (GCSM): Towards Implementing Sustainable Manufacturing, 31st October - 2nd November, Istanbul, Turkey.

Stubbs, W. and Cocklin, C. (2008), "Conceptualizing a "Sustainability Business Model”, Organization \& Environment, Vol. 21 No. 2, pp. 103-127. 
Teece, D. (2010), "Business model, business strategy and innovation”, Long Range Planning, Vol. 43 No. 2-3, pp. 172-194.

The Royal Society (2012), "People and the Planet", available at: http://royalsociety.org/policy/projects/people-planet/report/ (accessed 22 April 2013).

Tukker, A. and Tischner, U. (Eds) (2006), New business for old Europe - Productservice development, competitiveness and sustainability, Greenleaf, Sheffield.

Yacooub, A. and Fresner, J. (2006), Half is Enough - An Introduction to Cleaner Production, LCPC Press, Beirut.

Yunus, M., Moingeon, B. and Lehmann-Ortega, L. (2010), "Building Social Business Models: Lessons from the Grameen Experience", Long Range Planning, Vol. 43 No. 2-3, pp. 308-325.

Zott, C. and Amit, R. (2010), "Business Model Design: An Activity System Perspective”, Long Range Planning, Vol. 43 No. 2-3, pp. 216-226.

Zott, C., Amit, R. and Massa, L. (2011), "The Business Model: Recent Developments and Future Research", Journal of Management, Vol. 37 No. 4, pp. 1019-1042.

\section{Appendix A. Populated example of the tool for LED lights}

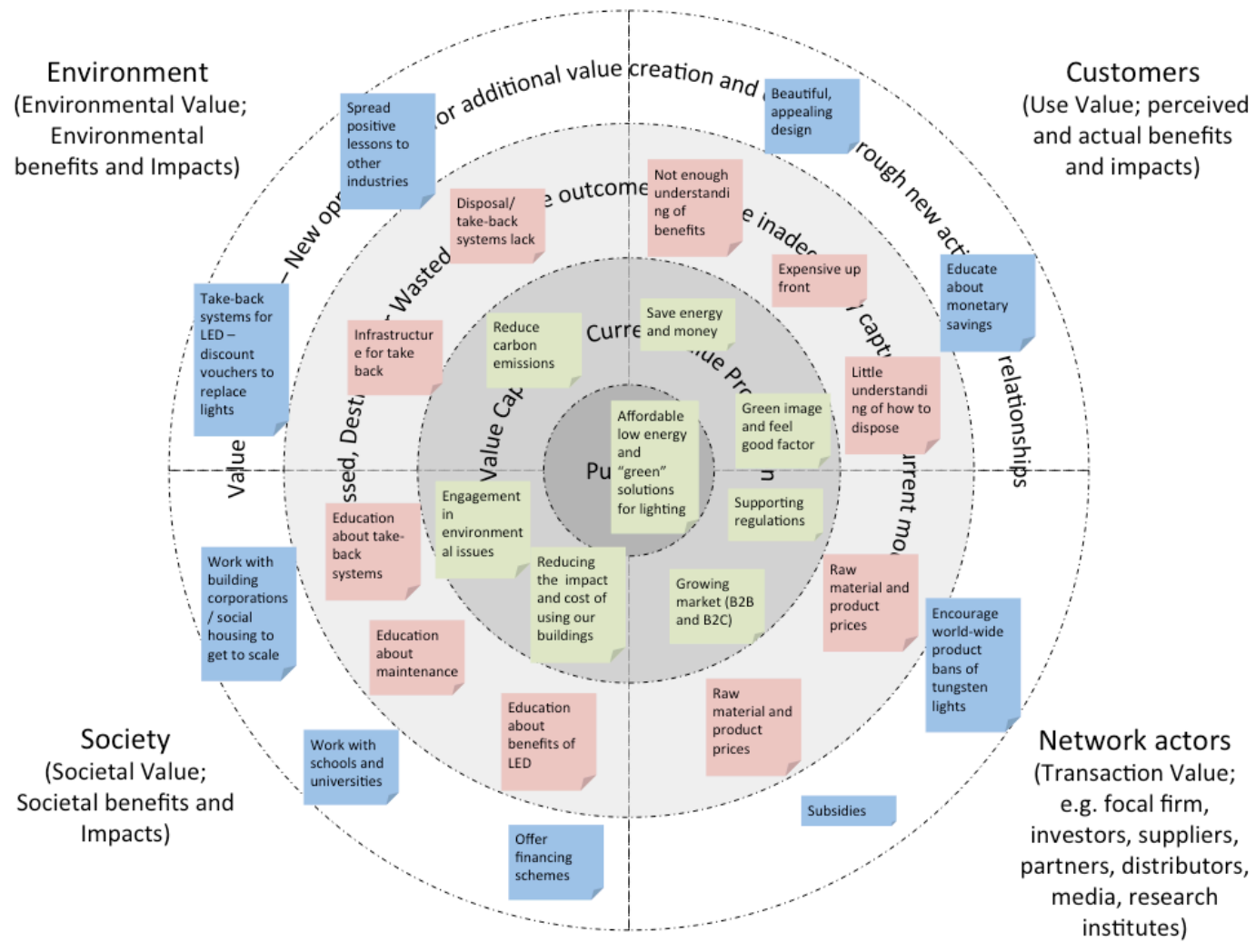

